\title{
Anonymous, studio production executive
}

Since 2004, Anonymous has been the head of production for a major television studio, overseeing scripted, reality, and first-run syndication programming. As outlined in this interview, studio budgets are a balancing act between creative production issues and the financial parameters of each project, which these days are significantly affected by the choice of production locations and the associated subsidies.

At what point in the development process do you start reading scripts?

Over the course of a year, the studio will hear at least a hundred pitches. As those ideas start to gain a little heat, I start reading them. I start talking to the showrunners about what they envision for the series. Between the conversations and the scripts, I am pretty good at figuring out ballpark costs. No one really knows how much money I spend but me. When television viewers see the New York skyline on their TV screens, they think they're seeing New York. They don't know how much it costs to make Los Angeles or Atlanta look like New York. Most show creators don't know those costs, either. I spend a lot of time giving them an idea of what their show is going to cost and how we might bring it in line with a more feasible budget. Can we shoot this scene at night instead of day? Can you set the story here instead of there? Can we film the series here instead of there? I'm showing them what they gain or lose, creatively and financially, in those various scenarios. This process becomes more and more fine-tuned as the script continues through development. 
What aspects of the script jump out at you? Is there a method to the madness, or is each script different?

I immediately look at location and action. I call them toys. If a show proposes big-name talent whose characters fly all over the world in precarious situations to blow stuff up, that's a nightmare. We simply can't afford to do it the way it needs to be done in order to maintain the level of quality we expect. Obviously, this entails a careful examination of the pilot script to remove extraneous elements or creative flourishes that pose significant impacts to the budget. I'm always asking the showrunners: Are these elements absolutely necessary to the story? It may be exciting to blow up three buildings in the pilot episode, but we can have the same impact with a third of the cost if we only blow up one.

\section{Do scripts have casts attached when you review them?}

No, but they usually have names in mind. I can get a sense of who is on their mind and what level of talent we're considering. For me, it's important to know: Are we talking name talent or no-name talent? Generally they'll want God, and I have to tell them we can't afford Him.

\section{So those are the "toys." What about locations?}

I'm immediately thinking about locations. The process entails a careful consideration of the space and place of the narrative-what locations are required for the story and where they are available. This requires an intimate knowledge of what a location has to offer and what creative variety is available there. It doesn't make sense to shoot a jungle series in New York, no matter how competitive the incentive. So, what do we need creatively to film the series, and what locations offer what we need for what cost? Oftentimes we can do more creatively-get more bang for our buck-if we look at locations outside Los Angeles.

\section{How do you determine that bang for your buck? Is it all about the incentives?}

First I look closely at the script to determine what it needs creatively. It doesn't mean the production isn't mobile, but I want to make sure I'm not considering a location that simply doesn't work creatively. Remember, too, I'm not dealing with features where you have the luxury of prep time. I'm doing series television where I'm often prepping a production without final scripts.

Then I'll look more closely at the incentives. Everything changes so quickly. It's practically a full-time job to keep tabs on who is offering what at any given time. 
But this is also why it's important to know what's happening: it keeps the world at our disposal. We can go anywhere. Is it more cost effective to re-create Chicago in Atlanta? Or do we just film in Chicago? If there are lots of toys, I'll start pushing for a competitive location. Does it have it to be Los Angeles? Why can't it be New York or Philadelphia? We're still early enough in the development process that these pitches are very similar to dating. Everyone is very receptive to my ideas because they want their show to get made. If you're dating someone you fancy, you're willing to do anything to get their attention. I used to go to flower shows all the time with my wife. I don't go to flower shows anymore. My point: it's easy for the creatives to agree with me while we're still in the romance stage; it's more difficult once the show is picked up.

So creative variety, incentives, and ...?

If a location has a competitive incentive, it's critical to also offer a solid physical infrastructure, crew depth [referring to the size and skill of the labor pool], and, for international locations, a competitive exchange rate. A successful television series will need a permanent home for a long time. It's nearly impossible to do a television series in a location without a studio or necessary equipment, like your cranes and other rigs. Given the budget and time constraints in television, it's equally important to have a highly skilled crew ready to jump into the trenches with us.

If you don't have an infrastructure or crew base, then we have to bring our own. We're bringing in more individuals, paying for more car rentals, accommodations, and per diem, and shipping the equipment we need to get the job done. You lose the tax credit.

Each factor can impact a production's degree of mobility, its costs, and its creative possibilities.

Absolutely. There are also the more intangible factors, like convincing talent and crew that spending eight months in Budapest away from their friends and families is a necessary adventure for the creative and financial well-being of a series. It's fun, but I'm sure not everyone enjoys it to the same degree.

Does it ever get to a point where you have to say to the showrunner, "Look, the numbers aren't working. We can't go forward with this show"?

At the end of the day, you can do any show for any price if you're willing to live with the outcome. My perspective is that it doesn't do anyone any good to run a show cheaply and efficiently if the final product sucks. You'll never hear me say, "I 
can do this cheaper, but it's going to look like shit." I'm at the table pitching reasons to my counterparts on the creative side why we can't do X or Y but can do Z to achieve the same effect.

I'm likewise there to prevent any financial surprises after filming starts. I'll read the script, then tell the showrunner that his or her series will cost X. The showrunner will start removing all this extraneous stuff and ask, "Okay. What about now?" I'll say, "It's still X because I already removed all the fluff when I read it the first time." I'm always budgeting things in my mind. I'm always removing what I know will make it an impossible project. I'm not as close to the project as the showrunner. It's sometimes easier for someone with some distance to identify what a viewer will or will not miss.

Sometimes I win battles. Sometimes I lose them. But the studio has limits. We have to have limits. We're in the business of making quality television, and my job is to figure out how we can do that realistically without compromising an idea's creative integrity.

So you're focused on numbers, but your job has some creative elements to it as well.

Don't tell anybody that!

We won't characterize you as a creative if you don't want us to.

I'm teasing. I like to think my counterparts at other studios are all doing various iterations of my job. I don't know. I've looked at my job, thinking it's very easy to say no or it's very easy to say yes. My challenge is how to serve both masters: the creative master and the financial master. I can simply dismiss an idea because it's too expensive. But what's the fun in that? The more exciting part for me is to figure out how I can help make sure that this idea, which might be initially too costly on paper, actually gets on television. I don't want to say no. I want to make it happen.

Do you work a lot with local film commissions when you're planning a production?

You always use the film commissions or film offices. They will hook you up with the local crew base. They will point me to the people I need to do the production there. We're a big company and at home in L.A., we don't need anyone else to do what we do. But if you're venturing into less familiar locations, the film commissions are critical. They help us secure permits and navigate local bureaucracies. They provide lists of available workers. They help us navigate the logistics of ensuring a smooth transition from here to there. 
When we try to explain this process to our students, they immediately think about travel costs, lodging costs, shipping costs-all the expanded logistics. They wonder if the incentives actually compensate for what you're spending.

You can tell them the math works. If we're going to the right locations, we only have to take the key people with us. Department heads and key crew members will travel with the production. We make sure they're very well accommodated no matter where they go-they're treated well when they travel. There's little resistance there. Talent is a little more difficult. You have to figure out who they are and how best to appeal to them. If it's an established individual, I'll go to hell and back to get them to agree to go to Hawaii. Cable television was easier in its infancy because we were dealing with less-established talent, or the big names were doing passion projects on cable and were willing to do whatever was necessary to get it made. It's not so anymore. Today cable is a big game. And the reality is simple: if you do this series in Los Angeles, you're going to have $\$ 200,000$ less to do your show. And that pays for a lot.

In all fairness, we are asking for an eight-month commitment. And if the show works, it's five, eight, ten years of your life. No matter how great the place is or how great we're treating them, they're away from family, friends, and significant others.

Who else finds themselves increasingly mobile? Talent, for sure. Writers? Directors?

Staff writers for television drama don't travel. They can be based in one place while the series films in another. Comedy, because of the hectic schedule, requires the writers to stay close to the product. So if it's filming in Los Angeles, they're in Los Angeles. If it's filming in New York, they're in New York. Showrunners must stay in touch with what's happening on set. They don't have to be there all the time, so they'll fly back and forth between their home base and the filming location.

Who are the key intermediaries, then, between the financial and creative managers in Los Angeles and the folks working on the shoot in Atlanta or Budapest or wherever?

On the creative side, the key intermediaries are the director who is there on the set and, to a lesser extent, the showrunner, just because he or she spends time on location. There's also an executive producer on the creative side who spends a lot of time flying back and forth.

On the financial side, I always have an executive producer who reports back to me. I also am very close to the line producer, who helps me keep tabs on what's happening on the ground. I'll spend some time flying back and forth, but I really 
rely on those key positions to keep me in the loop. There's too much money on the line not to keep an eye on how the production is unfolding.

Which locations are getting the most work these days?

We have L.A. Chicago. We'll do the United States first. Portland. New York. Then we have Budapest. We have Australia. We have some cable in Canada. We have some first-run in Connecticut.

Are those the most competitive locations?

Clearly New York is. Australia is a great place to shoot abroad. So are Budapest and Prague.

What does it take to turn a location into a production hub? We often hear: at least one TV drama series with a long-term commitment.

No, it takes more. It takes consistency. As you do more in a location, you build more capacity. People move there. Skills grow stronger. Services develop. If you're relying on one series, everything goes away when that series ends.

You mentioned earlier that tracking incentives is practically a full-time job. How do you do it?

One, I'm a workaholic, which is to the detriment of my family, but it has helped me greatly. I'm usually in the office by five in the morning. I usually leave somewhere around midnight. Sometimes it feels like twenty-four hours a day, seven days a week. 